УДК 37.013.2:371.32.

DOI:

Наталія Гречаник, кандидат педагогічних наук, доцент кафедри педагогіки і психології початкової освіти

Глухівського національного педагогічного університету імені Олександра Довженка

Сергій Пішун, кандидат педагогічних наук, доиент кафедри педагогіки і психології початкової освіти

Глухівського національного педагогічного університету імені Олександра Довженка

\title{
ХУДОЖНЬО-СПЕЦИФІЧНІ ПРИНЦИПИ ІНТЕГРОВАНОГО ВИКЛАДАННЯ МУЗИЧНОГО МИСТЕЦТВА В ПОЧАТКОВІЙ ШКОЛІ
}

У статті зроблена спроба аналізу художньо-специффічних принципів, траєкторій їх функціонування й реалізації в прочесі навчання учнів початкової иколи на уроках музичного мистецтва. Задекларовані принципи розглядаються як методологічний підхід, який у взаємодї з іншими видами мистеитва забезпечує розвиток молодшого школяра з позичій гармонії зі світом природи, суспільства й культури, які, з погляду виховання духовних і соиіально значущии орієнтирів особистості, набувають максимально ефективної реалізації.

Ключові слова: інтеграція; компетентність; молодші школярі; музичне мистецтво; поліхудожність; принциипи; урок.

Puc. 1. Лim. 6.

Nataliya Hrechanyk, Ph.D.(Pedagogy), Associate Professor of the Pedagogy and Psychology of Primary Education Department

Hlukhiv Oleksander Dovzhenko National Pedagogical University

Serhiy Pishun, Ph.D.(Pedagogy), Associate Professor of the Pedagogy and Psychology of Primary Education Department Hlukhiv Oleksander Dovzhenko National Pedagogical University

\section{ARTISTIC AND SPECIFIC PRINCIPLES OF INTEGRATED TEACHING OF MUSICAL ART IN PRIMARY SCHOOL}

A system of artistic principles is explained in the article. The peculiarity and use of such principles is essential for the effectiveness of integrated topical musical art lessons. Mastering these principles by a teacher facilitates to understanding a compound artistic content by primary school pupils in interdisciplinary topical lessons, ensures their development in consonance with the world of art, social and natural environment. Together with didactic and other artistic and specific principles they are to control pedagogical process at integrated art lessons and to lead to the achievement of the main objective that is to form a real view of life by primary school pupils.

The main condition is the cooperation of a music teacher with teachers of other disciplines, concurrence in realization of common methodological approaches, didactic and artistic principles and methods that facilitate to mastering an integrated complex of artistic content of education by pupils.

In the article we proved a synthesizing role of music, its interaction with other kinds of art due to the resonance effect - a basic music characteristic in the process of its perception by pupils. It forms in the pupils, consciousness ability to inner understanding of multiartistic material (music, literature, art) and ensures the world perception by primary school pupils from the perspective of integrity, artistic and figurative content, perception of world as a true picture.

Insufficient work on theoretical consonances that allow to choose and structure a learning material of art disciplines into unified didactic units as a basis for integrated teaching, and unwillingness or inability to use methods that favor to content diffusion of different arts in education process, is an obstructive factor in the integrated processes of art education of primary school pupils.

Displaying the different artistic abilities of primary school pupils under the conditions of integrated process at art lessons gives an opportunity to ensure its wider and full artistic development, to broaden a common cognitive base (world perception, thinking, imagination, speech) as a basis for successful mastering other academic disciplines.

Keywords: an integration; a competence; primary school pupils; musical art; multiartistry; principles; a lesson.

ПI остановка проблеми в загальному вигляді. Сучасне навчання, і мистецьке зокрема, грунтується на засадах особистісно зорієнтованогой компетентнісного підходів, визначених в основних нормативних документах освіти - державних стандартах, навчальних планах, програмах. В оновленому стандарті, як підкреслює О. Савченко, компетентнісна 


\section{ХУДОЖНЬО-СПЕЦИФІЧНІПРИНЦИПИ ІНТЕГРОВАНОГО ВИКЛАДАННЯ МУЗИЧНОГО МИСТЕЦТВА В ПОЧАТКОВЙ ШКОЛІ}

освіта в індивідуальних досягненнях стосується, перш за все, творчої сфери (я створюю, я змінюю, я знаходжу, я доповнюю) і емоційно-ціннісної (я прагну, я хочу досягти, я дуже ціную, я схвалюю, я відчуваю, що мені потрібно) [4, 4]. У початковій школі урок музичного мистецтва - це основна форма як музичної освіти, так і естетичного виховання учнів. Від організаційного компоненту й ефективного професійного проведення уроків залежить рівень реалізації тих завдань музичної освіти, що постають перед молодим поколінням. Кожен урок повинен бути завершеним та цілісним і водночас бути частиною системи уроків, пов'язаних між собою загальною метою й загальними завданнями, зазначає О.Я. Ростовський $[3,455]$. Як шкільний предмет заняття 3 музичного мистецтва повинні відповідати тим базовим вимогам, що ставляться до уроків 3 інших предметів. Однак специфічність взаємодії молодших школярів з музикою передбачає процес трансформаційності змістузагальнодидактичних вимог з їх спрямованістю на розуміння музики як мистецтва, що визначає необхідність урахування вчителем атрибутів уроку музики як уроку мистецтва.

Оволодіння вчителем принципами й методами роботи, адекватними природі мистецтва й особливостям його сприйняття молодшими школярами, - найважливіший щабель, що передує виходу за межі вузького предметного підходу й сприяє подоланню міждисциплінарної роз'єднаності в освоєнні змісту мистецької освіти учнями. Інтегрована взаємодія вчителів музики, літератури, образотворчого мистецтва можлива на основі оволодіння ними теорією, принципами (не тільки загальнодидактичними, а й специфічними) та методикою інтеграції суміжних видів мистецтва в межах свого предмета.

Виховання молодших школярів засобами декількох мистецтв вимагає брати до уваги не тільки систему дидактичних вихідних положень у здійсненні процесу естетичного виховання (науковість, систематичність, доступність, зв'язок з життям, наочність тощо), а й суто специфічні принципи побудови мистецьких занять (цілісність вивчення мистецтв, в основі яких функціональні зв'язки, урахування специфіки певного виду мистецтва, чуттєве й логічне в їх оптимальному поєднанні, творча активність школярів шляхом їх безпосереднього включення в систему художньо-естетичних відносин. Урок мистецтва як певна структурна побудова відзначається динамікою його елементів, залежних від основної дидактичної мети, від логіки й закономірностей розв'язання поставлених на певному уроці завдань художньо-творчого розвитку учнів $[1,219]$.

Аналіз останніх публікацій та досліджень. Аналіз багатьох сучасних досліджень стосовно музично-естетичного розвитку молодших школярів орієнтує нас на використання виховних можливостей мистецтв як системи, у якій сумарність сполучень реалізується в їх різновидах. Так, дослідники О. Курєвіна, Л. Масол, Л. Предтеченська, О. Щолокова, Б. Юсов зазначають, що інтегроване навчання, у межах якого відбувається взаємопроникнення й систематизація знань учнів, формування в них цілісного світосприйняття, розвиток творчих здібностей і гнучкого мислення, $\epsilon$ більш ефективним. Проблемам підготовки майбутніх учителів у галузі мистецької освіти присвячено праці Т. Завадської, Н. Миропольської, О. Олексюк, О. Ростовського, О. Рудницької, Л. Хлєбникової, В. Черкасова [6]. Проблеми розвитку музичної педагогіки, мистецтва, його інтеграційного освоєння взагалі й музики, зокрема, стали предметом науково-практичних досліджень таких учених, як: Л. Архімович, С. Горбенко, М. Гордійчук, М. Грінченко, М. Зинькевич, А. Лащенко, I. Ляшенко, А. Мартинюк та ін.

Мета статті полягає в розкритті характерних особливостей художньо-специфічних принципів у процесі інтегрованого навчання музичному мистецтву учнів початкової школи.

Виклад основного матеріалу. В основі методики підготовки й проведення інтегрованих занять мистецтва лежать насамперед основоположні закономірності загальної педагогіки, а також художньо-специфічні принципи, висунуті в музикознавстві, музичній та художній педагогіці як властиві художньо-образній природі мистецтва й специфіці його засвоєння школярами. Дидактичні принципи міжпредметних зв'язків та інтеграції, обгрунтовані в загальній педагогіці, як правило, ототожнюються вчителями в освітній практиці, у тому числі на уроках мистецтва. Просте механічне поєднання окремих знань та уявлень про світ, що одержані учнями на різних предметах за зовнішньою, формальною ознакою, сюжетною подібністю, хронологічним збігом подій, іноді кваліфікують як інтеграцію. У практиці викладання уроків мистецтва такий підхід супроводжується примітивною ілюстрацією одного виду мистецтва іншим з аналогічним змістом і не співвідноситься $з$ розумінням сутності ієрархічної інтеграції як взаємодії, взаємопроникнення іiї компонентів.

Зауважимо, що висунуті художньо-специфічні принципи затребувані методикою освітньої 


\section{ХУДОЖНЬО-СПЕЦИФІЧНІ ПРИНЦИПИ ІНТЕГРОВАНОГО ВИКЛАДАННЯ МУЗИЧНОГО МИСТЕЦТВА В ПОЧАТКОВІЙ ШКОЛІ}

практики, і поряд із загальнодидактичними принципами допомагають учням сформувати відповідне світосприйняття.

Художньо-специфічні принципи та їх класифікація

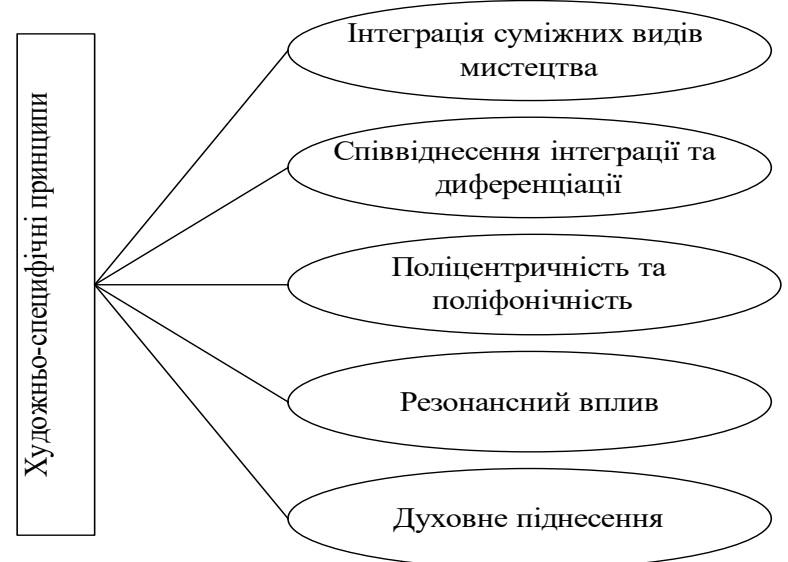

Рис. 1. Схема класифікації художньо-специфічних принципів

Принци інтеграції суміжних видів мистецтва уточнює сутність ієрархічної інтеграції, що організує навчальний процес на рівні викладання окремих предметів (внутрішньопредметна інтеграція) і нарівні міжпредметних тематичних блоків (міжпредметна інтеграція). Тема блоку ієрархічно упорядковує й організовує взаємодію між окремими рівнями інтеграції по вертикалі й горизонталі. Вона визначає художньо-педагогічну ідею та спрямованість занять як на окремих уроках музики, літератури, образотворчого мистецтва, так і процесу проведення інтегрованих занять. Блокова інтеграція - взаємопроникнення 3 декількох різних областей знання тем, ідей, методів, теорій (на уроках музики вона буває або тематична, наприклад, тема моря в музиці, образотворчому мистецтві й літературі; або мистецтвознавча, що дає значне число “ступенів свободи через поєднання, аналіз та узагальнення різних видів мистецтва, а не окремих творів або їх тематики) [5, 107 - 111]. Міжпредметна інтеграція в блоках можлива лише на основі внутрішньопредметної інтеграції, що здійснюється на рівні викладання музики, літератури, образотворчого мистецтва як самостійних предметів.

Цілісне мислення, живе світосприйняття, гармонійна особистість - усі ці якості $€$ результатом інтегрованої взаємодії мистецтв в освоєнні художньої освіти школярами. Досягнення цих якостей, як показує практика, пов'язане 3 кардинальною перебудовою педагогічного мислення вчителя і структури загальної шкільної освіти на користь мистецтва. Розвиток творчого потенціалу як здатність створювати чуттєві образи інтенсивно відбувається на суміжних уроках літератури, музики, образотворчого мистецтва. Але більш продуктивно розвиток творчості здійснюється в процесі інтегрованого викладання предметів мистецтва. Види мистецтв та їх інтеграція в розвитку творчого ресурсу молодших школярів покликані виховувати почуття краси, гармонії, розвивати емоційноінтелектуальну й чуттєву сферу особистості. Мета вивчення інтегрованого курсу “Мистецтво” у процесі сприймання та інтерпретації творів мистецтва, практичної художньо-творчої діяльності формувати в учнів комплекс ключових, міжпредметних естетичних і предметних мистецьких компетентностей, який забезпечить здатність до художньо-творчої самореалізації особистості [2].

Принцип співвіднесення інтеграції та диференціації. Співвіднесеність означає збалансованість, урівноваженість, досягнення гармонії процесів розвитку. Інтеграція й диференціація - зовні протилежні тенденції, що позначають складний динамічний процес еволюції людської свідомості й усього матеріального світу, але внутрішньо вони не існують одна без одної. Принцип співвіднесеності в інтегрованому підході до формування світогляду та світосприйняття молодших школярів на заняттях мистецтвом передбачає регулювання балансу між цими протилежними сторонами процесу розвитку.

Інтегрований підхід реалізується в рамках традиційної класно-урочної системи, яка оформилася в результаті розчленування сукупності людських знань про світ на окремі галузі знання - про природу, людину, суспільство. Кожен вид мистецтва як предмет вивчення у школі є результатом диференціації знань та уявлень про світ. Кожна диференційована одиниця (навчальний предмет) неодмінно відтворює властивості цілого (блоку), його тему й художньопедагогічну ідею. Концентроване узагальнення, емоційно-інтелектуальний синтез, цілісне уявлення про світ як живий організм неможливі без конкретного бачення його складових (диференціації). Принцип співвіднесеності інтеграції та диференціації не виключає предметну систему навчання, а, навпаки, спирається на іiі фундаменті як функціональній підставі. Інтегроване викладання мистецтва здійснюється на основі монохудожнього засвоєння різних видів мистецтва й художньої творчості дітей. 


\section{ХУДОЖНЬО-СПЕЦИФІЧНІПРИНЦИПИ ІНТЕГРОВАНОГО ВИКЛАДАННЯ МУЗИЧНОГО МИСТЕЦТВА В ПОЧАТКОВІЙ ШКОЛІ}

Інший аспект інтеграції та диференціації стосується дитини, яка повинна розглядатися як еволюційна індивідуальність. Ми виходимо з того, що кожній дитині спочатку притаманні не тільки здатності індивідуальних здібностей, а й від природи надані їй можливості їх розвитку. Гранична можливість диференціації полягає в індивідуалізації освіти з урахуванням здібностей і можливостей кожного окремого учня, що, в силу об'єктивних причин, досить важко реалізувати в сучасній загальноосвітній школі. Індивідуальність як вираз граничної диференціації може реалізувати свій творчий хист через інтеграцію власних зусиль в колективних формах життєдіяльності, пізнання й творчості. Саме в інтегрованій діяльності кожен учень отримує право вибору того художнього прояву своєї індивідуальності, до якого схильний від природи.

Принцип поліцентричності та поліфонічності стосовно інтегрованого підходу у формуванні світосприйняття в школярів означає, що в навчальному процесі школи немає головних предметів, що стоять в центрі уваги вчителя, i другорядних предметів, без яких можна обійтися, що має місце в традиційній предметоцентристській моделі школи.

Центр - одночасно скрізь. Центр поліфонічний (багатоаспектний) і поліцентричний, оскільки на одному й тому ж інтегрованому занятті центральними можуть бути різні форми сприйняття й художньої творчості: візуалізація музичних образів, їх пластична й музичноритмічна реалізація, знаходження літературнопоетичних аналогів музичного змісту, інсценування, ілюстрування літературного тексту, інші види дитячої творчості. Художній зміст підноситься школярам полісенсорно, тобто програється то в слуховому, то в зоровому, то в кінестетичному варіантах, то в усіх одночасно. Відбувається постійне переміщення центру 3 одного виду мистецтва на інший, то центр одночасно - скрізь. У результаті в уяві дітей виникає відчуття постійного руху. Картина світу під впливом музики в синтезі з іншими видами мистецтва формується об'ємно, багатогранно, стає живою.

Інший аспект прояву зазначеного принципу полягає в перенесенні центру з вивчення предмета на внутрішній світ дитини, його світосприйняття в процесі освоєння змісту творів музики, літератури, образотворчого мистецтва. Колектив учнів у класі розуміється як поліфонія індивідуальностей, де голос кожного звучить і чутний в хорі голосів, що гармонійно зливаються, оскільки полісенсорна подача матеріалу дозволяє всім дітям і кожному окремо почути, побачити й проявити себе, почути й побачити інших, і злитися в єдиному переживанні прекрасного, що несе в собі мистецтво. Скільки в класі дітей, стільки центрів індивідуального світовідчуття, світосприйняття, світовідношення. Діти - центр педагогічного процесу.

Принцип поліцентричності та поліфонічності, керуючи педагогічним процесом на інтегрованих заняттях мистецтвом поряд з іншими принципами, “прибирає” кордон між предметами, між різними видами мистецтва та художньої творчості. У школярів виникає уявлення, що предметом вивчення на уроці мистецтва $є$ життя, різні його прояви, виражені через мову різних видів мистецтва. Непомітно для самого себе молодший школяр тренується у вільному переході від музичного образу до образотворчого, літературного й навпаки. При цьому більш інтенсивно формуються його поліхудожні здатності до творчості в різних видах мистецтва одночасно.

Принцип резонансного впливу. Ефект резонансу можна визначити як сутнісну властивість музики й обов'язкову умову адекватного сприйняття. Він розширює поняття резонансу стосовно музики як звукової форми вираження життєвого змісту, яка не має явного, певного значення. В обгрунтуванні принципу резонансного впливу треба виходити з розуміння резонансу як якісної хвильової характеристики звуку. Явище резонансу в музиці має на увазі наявність живого джерела (людини), яка відповідає на коливання хвиль звукового походження, що викликає аналогічну вібрацію в їі тілі й свідомості. Звукова природа резонансу сходить до пульсуючого руху або вібрації повітряних потоків - найтоншої суті руху, що властива всьому живому.

Резонанс як збіг вібрацій, їх співзвуччя $\epsilon$ якісною характеристикою звуку та сприйняття людини. Позитивна взаємодія дитини 3 мистецтвом обумовлена виникненням ефекту резонансу (співзвуччя) у процесі навчання. Звук як результат прояву руху лежить в основі всього живого, життя - світобудови, природи, людини, мистецтва. Музика - звуковий прояв життя, вона $\epsilon$ потужним джерелом, зверненим, перш за все, до слуху, але резонансно збудливим відгуком в інших сенсорних системах і синтезує в собі їх якості в єдиний, пульсуючий, живий образ на рівні свідомості. Розвинене музичне почуття означає здатність вібрувати в резонансі із зовнішніми детермінантами, що впливають на дитину, реакцію на звучання живого світу. 


\section{ХУДОЖНЬО-СПЕЦИФІЧНІПРИНЦИПИ ІНТЕГРОВАНОГО ВИКЛАДАННЯ МУЗИЧНОГО МИСТЕЦТВА В ПОЧАТКОВІЙ ШКОЛ}

Зазначений принцип передбачає не пряме навчання музиці як навчальному предмету, який вивчають, а резонансний вплив на духовний світ дитини в процесі:

- полісенсорного сприйняття творів одного виду мистецтва;

- одночасного сприйняття творів різних видів мистецтва.

Завдяки виникненню ефектурезонансу школярі вчаться візуалізувати музичний образ в уяві, відчувати його аромат, насиченість світла або тіні, колориту музичного простору, його обсягу (вертикально-горизонтального виміру), тимчасових, температурних та інших характеристик, співвідносити й усвідомлювати їх взаємозв'язок у створенні музичного образу. У результаті систематичного формування та розвитку в молодших школярів здібностей полісенсорного сприйняття на основі принципу резонансного впливу, у їхніх уявленнях виникає більш об'ємна, цілісна художньо-образна картина живого світу, що звучить, пробуджує зацікавленість до пізнання світу через мистецтво, стимулює приховані лінії індивідуального розвитку. Музика в силу своєї резонансної природи на інтегрованих заняттях мистецтвом $\epsilon$ потужним інтегруючим фактором, що підсилює вплив різних видів мистецтва на свідомість дитини, сприяє самовизначенню дітей в перевагах того чи іншого виду мистецтва i творчості, формує їх живе світосприйняття.

Принцип духовного піднесення. Існує безліч тлумачень духовності, але більшість 3 них виходять з релігійного розуміння її суті. У нашому розумінні духовність - це поняття надрелігійне, наднаціональне, надпрофесійне. Світський характер передбачає релігію поза освітою, а в школі повинні виховуватися духовні якості дитини доступними педагогіці засобами. Людину робить духовною не тільки слідування певній вірі, релігіі, ідеї. Прорив до духовності реалізується від усвідомлення безмежних можливостей і потреб людини - стати духовно розкритою особистістю, не виходячи $з$ кола повсякденного реального життя. Саме духовність визначає моральне, інтелектуальне й фізичне благополуччя людини. Сприймаючи зміст твору, дитина безкорисливо й щиро співпереживає образам мистецтва й співвідносить себе 3 ними, виробляючи власну позицію по відношенню до людських характерів, явищ світу за законами краси.

Педагогічний сенс духовності ми розглядаємо як загальну якість особистості, що формується в активній дії за рахунок власних внугрішніх резервів дитини, і визначає духовність як зв'язок людини із загальною сукупністю явищ, виражену в мові наочних, звукових та інших сенсорних образах, а також у формі думки.

Висновки. Підсумовуючи сказане вище, зазначимо, що висунуті нами принципи: інтеграції суміжних видів мистецтва, співвіднесеності інтеграції та диференціації, поліцентричності та поліфонічності, резонансного впливу, духовного піднесення за основними ознаками $є$ загальнохудожніми та покладені в основу взаємодії музичного навчального матеріалу, літератури, образотворчого мистецтва в процесі їх засвоєння школярами на інтегрованих заняттях мистецтвом. Наведені принципи уточнюють і конкретизують різні грані загального принципу цілісності як закону розвитку всього, що існує. Ця діяльність спрямована на вслухування, уживання в поліфонію внутрішнього й зовнішнього світу, що звучить, і на цій основі пізнання себе й всесвіту в єдності, усвідомлення себе як духовно-моральної особистості.

\section{ЛІТЕРАТУРА}

1. Падалка Г.М. Педагогіка мистецтва (теорія і методика викладання мистецьких дисциплін) / Г.М. Падалка. - К. : Освіта України, 2008. - 274 с.

2. "Про затвердження змін до навчальних програм для 1 - 4-х класів загальноосвітніх навчальних закладів" від 05.08.2016 № 948 . [Електронний ресурс] https://mon.gov.ua/ua/osvita/ zagalna-serednya-osvita/navchalni-programi/ navchalni-programi-dlya-pochatkovoyi-shkoli

3. Ростовський О. Я. Теорія і методика музичної освіти: Навч.-метод. посібник / О. Я. Ростовський. Тернопіль: Навчальна книга - Богдан, 2011. - 640 с.

4. Савченко О. Я. Новий держстандарт для початкової школи: від задуму до реалізації /О. Я. Савченко // Педагогічна газета. - 2012. - № 1(210). - C. 4.

5. Стрихар О. И. Експериментальні дослідження iз застосування принципу інтеграції в навчанні музичному мистецтву дітей / О. И. Стрихар // Вісник Черкаського університету: Серія педагогічні науки: науковий журнал. - Черкаси, 2013. - №3 (256). - 152 c.

6. Черкасов В. Ф. Теорія і методика музичної освіти: навч. посіб. / В. Ф. Черкасов // Серія “Альма-матер”. - К.: ВЦ “Академія”, 2016. - 240 с.

\section{REFERENCES}

1. Padalka, H. M. (2008). Pedahohika mystetstva (teoriia $i$ metodyka vykladannia mystetskykh dystsyplin) [Pedagogics of Art (Theory and Methodology of Art Disciplines Teaching)]. Kyiv: Education of Ukraine, 274 p. [in Ukrainian].

2. "Pro zatverdzhennia zmin do navchalnykh 
prohram dlia 1-4-kh klasiv zahalnoosvitnikh navchalnykh zakladiv" (2016). [On Enacting Amendments to Educational Programmes for the 14 Forms of General Education Institutions]. [Electronic resource]. Available at: https://mon.gov.ua/ua/osvita/ zagalna-serednya-osvita/navchalni-programi/ navchalni-programi-dlya-pochatkovoyi-shkoli [in Ukrainian].

3. Rostovskyi, O. Ya. (2011). Teoriia i metodyka muzychnoi osvity: Navch.-metod. Posibnyk [Theory and Methodology of Art Education: Study Guide]. Ternopil: Academic Book - Bohdan, 640 p. [in Ukrainian].

4. Savchenko, O. Ya. (2012). Novyi derzhstandart dlia pochatkovoi shkoly: vid zadumu do realizatsii
[New State Standard for Primary School: from Idea to Realization]. Pedagogical Newspaper, No.1 (210), p. 4. [in Ukrainian].

5. Strykhar, O. Y. (2013). Eksperymentalni doslidzhennia iz zastosuvannia pryntsypu intehratsii $\mathrm{v}$ navchanni muzychnomu mystetstvu ditei [Experimental Researches on Applying a Principle of Integration in Teaching Children Musical Art]. Journal of Cherkasy University. Series: Pedagogical Sciences. Scientific Journal, No.3 (256), 152 p. [in Ukrainian].

6. Cherkasov, V. F. (2016). Teoriia i metodyka muzychnoi osvity: navch. posibnyk [Theory and Methodology of Art Education: Textbook]. Series: Almamater. Kyiv: VTs “Akademiia”, 240 p. [in Ukrainian].

Стаття надійшла до редакції 04.01.2019

УДК $378.011 .3-051$

DOI:

Соломія Ілляш, кандидат психологічних наук, дочент кафедри педагогіки та методики початкової освіти Дрогобииького державного педагогічного університету імені Івана Франка

\section{РОЗВИТОК ПРОФЕСІЙНОГО САМОРОЗУМІННЯ В ПРОЦЕСІ ПІДГОТОВКИ МАЙБУТНІХ УЧИТЕЛІВ}

У статті досліджено проблему розвитку професійного саморозуміння в майбутніх учителів; проаналізовано психологічні аспекти проблеми саморозуміння; розглянуто основні підходи щооо вивчення та діагностики процесу розуміння; виокремлено суттєві ознаки та структурно-динамічні характеристики саморозуміння; розкрито зв 'язок професійно-педагогічної спрямованості і саморозуміння майбутніх учителів; визначено функиії та показники професійного саморозуміння; з 'ясовано способи впливу саморозуміння на успішність професійної діяльності майбутніх учителів початкової школи.

Ключові слова: самосвідомість; професійне саморозуміння; професійно-педагогічна спрямованість; професійно-педагогічна підготовка; майбутні вчителі; початкова школа; професійна діяльність.

Jim. 8.

Solomiya Illyash, Ph.D.(Psychology), Associate Professor of the Pedagogy and Methodology of Primary Education Department Drohobych Ivan Franko State Pedagogical University

\section{THE DEVELOPMENT OF PROFESSIONAL SELF-UNDERSTANDING IN THE PROCESS OF TRAINING OF FUTURE TEACHERS}

The problem of the development of the future teachers ' professional self-understanding is investigated in the article; it analyzes the psychological aspects of the problem of self-understanding and it establishes that a person does not understand herself at once; this ability develops gradually throughout life, under the influence of numerous social phenomena. The article reviews the main approaches to studying and diagnostics the process of understanding which scientists conditionally define as ,objective" and "subjective” ones. It is found out that the realization of the "objective" approach means a detailed study of the subject of understanding, its structural organization and internal regularities of the development. On the contrary, the "subjective" approach to the study of understanding is focused, first of all, on the study of mechanisms, the object of understanding is considered as a condition for the intellectual activity of the subject. The following features of self-understanding are singled out: depth, clarity and flexibility as well as some structural and dynamic characteristics of this personal formation. The article reveals the connection of professional pedagogical orientation and self-understanding of future teachers; it finds out that the concept of professional self-understanding is wider than the concept of pedagogical orientation. The concept of professional self-understanding includes the system of ideas about professional training, goals, tasks and results of professional self-improvement. The functions of self-understanding are singled out: inductive, cognitive and evaluative, regulatory. The indicators of professional self-understanding are determined. They are the motives which impel to 